\title{
Bioefficacy of Bacillus subtilis against Major Pathogen of Chilli Colletotrichum capsici Causing Fruit Rot of Chilli
}

\author{
K. Rajkumar ${ }^{1 *}$, M.K. Naik ${ }^{1}$, Y.S. Amaresh ${ }^{1}$ and G. Chennappa ${ }^{2}$ \\ ${ }^{1}$ Department of Plant Pathology, University of Agricultural Sciences, Raichur, India \\ ${ }^{2}$ Department of Processing and Food Engineering, University of Agricultural Sciences, \\ Raichur- 584104, India \\ *Corresponding author
}

\section{A B S T R A C T}

\section{Keywords}

B. subtilis,

Biocontrol, PGPR,

Per cent inhibition,

C. capsici

Article Info

Accepted:

20 June 2018

Available Online:

10 July 2018
Bacillus subtilis is one of the potential PGPR and biocontrol agent against several plant pathogens of important crop plants. In the present study thirty isolates of B. subtilis were isolated from different rhizosphere soil samples from different parts of North Eastern Karnataka region. All the rhizospheric isolates were rod shaped, positive for gram reaction, endospore, oxidase, catalase, starch hydrolysis, negative for indole, $\mathrm{KOH}$ test and green coloured colonies were grown on Hichrome Bacillus agar medium. All the thirty isolates of $B$. subtilis were tested for their efficacy against $C$. capsici under in vitro. All the isolates showed the varied level of inhibition of mycelial growth of $C$. capsici. Among different isolates, BS16 showed maximum 63.42 per cent followed by BS $30(57.40 \%)$ inhibition and minimum was 11.98 per cent in case of BS 24 compared to check (56\%). Biological control is by using antimicrobial agents an attractive option which reduces the use of chemicals in the management of diseases of chilli.

\section{Introduction}

Management of diseases of crop plants is difficult due to arrival of new races of pathogens. Chemical control is one of the options for management but bears risk of soil and water pollution. Pesticide residues have detrimental effects on human, plant and soil health and leads to development of mutant resistant to pesticides (Gerhardson, 2002). Hence, a biocontrol measure employing antagonistic bacterial agents is an attractive option (Han et al., 2005). Biocontrol is an important strategy to reduce the use of chemicals in disease management. Recently, a considerable attention has been given to some of the rhizobacteria which have positive influence on the plant growth and health. These are referred as Plant Growth Promoting Rhizobacteria (PGPR) (Schippers, 1992; Glick, 1995) such as Azatobacter, Pseudomonas, Azospirullum, Bacillus and Brukholderia. Among the PGPRs, the endospore forming, Bacillus subtilis is the one which plays a major role in plant growth promotion and biocontrol of pathogens (Glick, 1995). B. subtilis is a gram positive, rod shaped bacteria with peritrichous flagella 
(Nakano and Hulett, 1997). The colony morphology of the isolates exhibit a range from flat to filamentous or branching (Wafula et al., 2014), having either smooth or rough colony with colour ranging from white to cream. They grow well at $\mathrm{pH}$ ranging from 5 6.5 and temperature range of 25 to $35{ }^{\circ} \mathrm{C}$ commonly found situation in soil. B. subtilis is an endospore forming bacteria (Piggot and Hilbert, 2004) which helps the organism to persist in the environment until conditions become favourable (Wafula et al., 2014). B. subtilis shows strong positive results in the methyl red test, oxidase test, litmus milk reactions and lipid hydrolysis test. The organism shows weakly positive for catalase test, gelatin hydrolysis test and negative results for citrate reduction, urease test, arginine hydrolysis and fluorescence in King's B medium (Montealegre et al., 2003).

Plant growth promotion and bio control of plant pathogens by Bacillus spp. are achieved by antibiosis, competition, mycoparasitism (Korsten and De Jager, 1995) and induced systemic resistance in host plant (Lemessa and Zeller, 2007; Aliye et al., 2008; Ji et al., 2008). These mechanisms might act singly or in combinations by using extra-cellular lytic enzymes viz, chitinase, amylase, protease, lipase, xylanase and $\beta 1,3$ glucanase which exhibit antagonistic property because of degradation of cell wall of fungi and bacteria (Ramyabharathi and Raguchander, 2013), anti microbial compounds such as $\mathrm{HCN}, \mathrm{H}_{2} \mathrm{~S}$ and siderophore (Dinesh Singh et al., 2012) and antibiotics such as subtilin, surfaction, iturin, biofilm, difficiden, bacilomycin, bacilycin and fengycin (Loeffler et al., 1990) which is known to control a wide array of phytopathogens such as fungi, bacteria and nematodes. B. subtilis multiply rapidly, occupy all available niches, absorb nutrients and form biological screen around the root and prevents breeding, growth, invasion of harmful microorganisms (Timmusk et al., 2005; Haggag and Timmusk, 2008).
However, the success of any biological control programme depends on our clear understanding about the biocontrol agent, their ecology, environments, antagonistic mechanisms and population dynamics in the soil. The exact identity of strains to the species level is the first step in realizing the potential of any bio agent. Further, their study on the diversity regarding rhizosphere niche of different crops is a priority.

\section{Materials and Methods}

\section{Collection and isolation of $B$. subtilis isolates}

Thirty isolates of B. subtilis were collected from different rhizosphere soil samples of chilli, chickpea, cotton, groundnut, onion, marigold, mustard, niger, pegionpea, paddy, sorghum, sunflower and wheat crops of Bagalkot, Ballari, Raichur and Koppal parts of North Eastern Karnataka agro ecosystem by serial dilution and plate count technique on nutrient agar medium and designated as BS-1 to BS-30. An isolate collected from UAS, Dharwad (DBS-19) was used for comparison to assess the biocontrol efficacy and PGPR activity (Pankaj Kumar et al., 2012).

\section{Bioefficacy of $B$. subtilis isolates against Colletotrichum capsici}

The isolates of $B$. subtilis were screened in vitro for their antimicrobial properties against major pathogen of chilli Colletotrichum capsici causing fruit rot/ anthracnose of chilli by using dual culture technique. The bio-agent and the pathogen were inoculated side by side in a single Petri plate containing solidified PDA medium. Three replications were maintained for each treatment with one control by maintaining only pathogen. The plates were incubated for $4-5$ days at $28 \pm 1{ }^{\circ} \mathrm{C}$. The mycelial diameter of pathogen was measured in two directions and average was recorded (Sumana and Devaki, 2013). Per cent 
inhibition of growth of test pathogen was calculated using the following equation (Vincent, 1927).

$$
\mathrm{I}=\frac{\mathrm{C}-\mathrm{T} \times 100}{\mathrm{C}}
$$

Where;

I = Per cent inhibition of mycelium

$\mathrm{C}=$ Growth of fungal mycelium in control.

$\mathrm{T}=$ Growth of fungal mycelium in treatment.

\section{Results and Discussion}

The bacterium was isolated from soil collected from the rhizosphere soil of different crops serial dilution and plate count technique. The culture was morphologically identified based on characters such as shape, texture of colony, colony morphology and colour of colony.

Thirty $B$. subtilis isolates were evaluated in vitro against $C$. capsici. All the isolates recorded the varied level of inhibition of mycelial growth of $C$. capsici. Among different isolates, BS16 showed maximum 63.42 per cent followed by BS $30(57.40 \%)$ inhibition and minimum was 11.98 per cent in case of BS 24 compared to check (56 \%)
(Table 1). Among 30 isolates of B. subtilis, ten isolates were high; eleven isolates were showed moderate performance and seven isolates showed low performance (Plate 1) (Fig. 1). Anand et al., (2010) reported that a significantly highest inhibition of mycelial growth of $C$. gloeosporiods causal agent of anthracnose of pomegranate was noticed by Pf4 isolate $(81.43 \%)$ and least inhibition was noticed in Pf8 (47.02\%). The bacterial antagonists such as $B$. subtilis isolate (BSCB4) $P$. fluorescens isolate (ENPf1) and $P$. chlororaphis isolate (PA23) were found to be effective in inhibiting the mycelial growth of C. cassicola causing stem blight of P. amarus (Mathiyazhagan et al., 2003). Ashwini and Shrividya (2012) strains of Bacillus spp. from 15 chilli rhizosphere soil were screened for chitinolysis on chitin amended plates and their involvement in the suppression of few pathogens was determined. The selected isolate showed broad spectrum antagonism against Alternaria spp. (55\%), $C$. gloeosporioides (57\%), P. capsici (62\%), R. solani (42\%), F. solani (42\%), F. oxysporum (40\%) and Verticillium spp. (36\%).

Fig.1 In vitro bioefficacy of $B$. subtilis against $C$. capsici, the causal agent of anthracnose of chilli

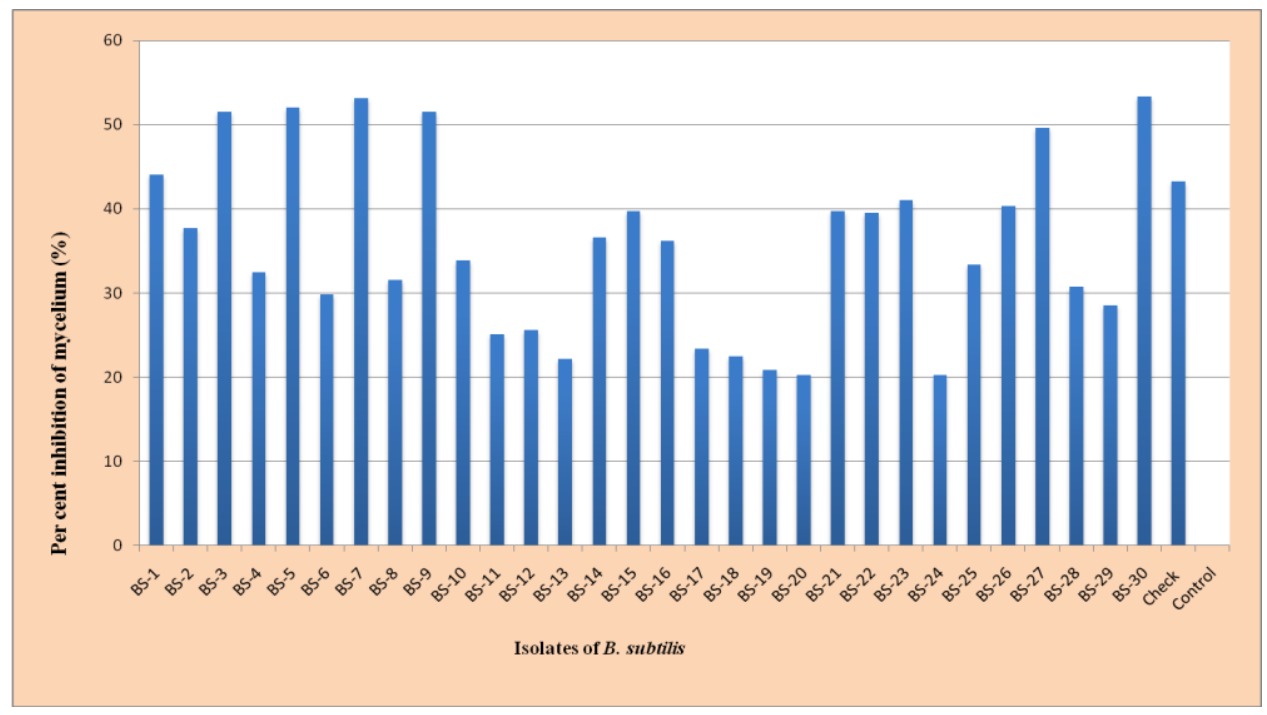


Plate.1 In vitro bioefficacy of $B$. subtilis isolates against $C$. capcisi, the causal agent of anthracnose of chilli

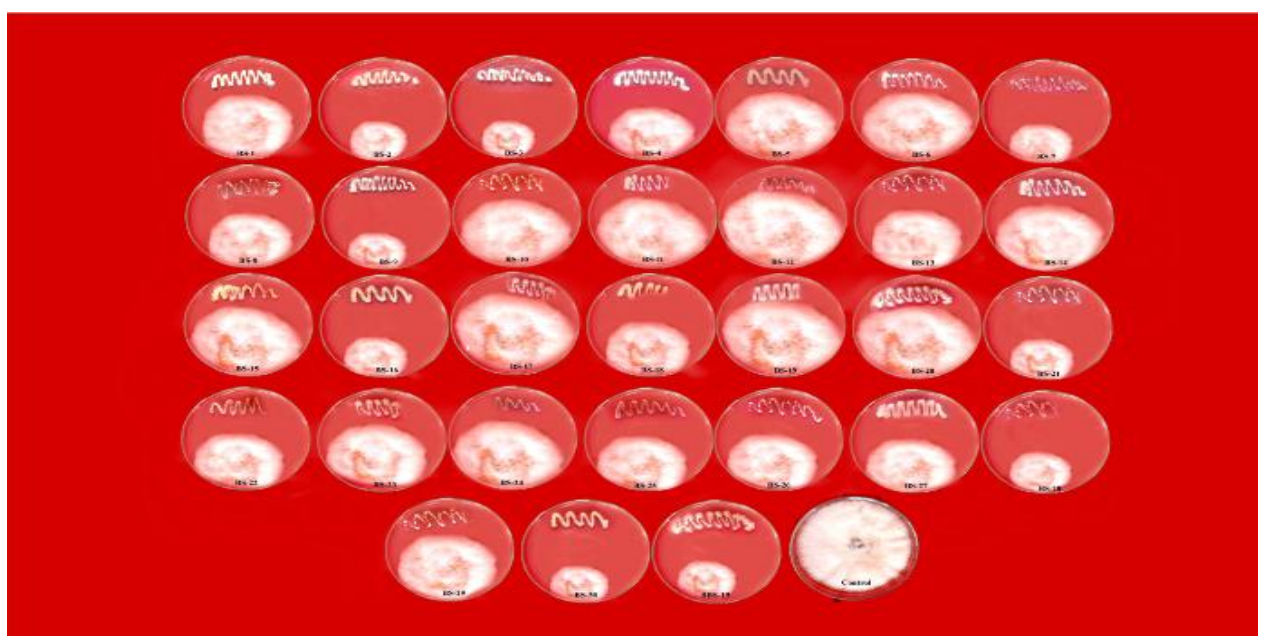

Table.1 In vitro bioefficacy of B. subtilis against $C$. capsici, the causal agent of anthracnose of chilli

\begin{tabular}{|c|c|c|c|}
\hline Sl. No. & Isolates & Per cent Inhibition & Remarks \\
\hline 1 & BS-1 & $40.82(39.70)^{*}$ & $\mathrm{H}$ \\
\hline 2 & BS-2 & $27.34(31.51)$ & M \\
\hline 3 & BS-3 & $31.00(33.00)$ & M \\
\hline 4 & BS-4 & $40.44(39.48)$ & $\mathrm{H}$ \\
\hline 5 & BS-5 & $43.07(41.00)$ & $\mathrm{H}$ \\
\hline 6 & BS-6 & $11.98(20.24)$ & $\mathrm{L}$ \\
\hline 7 & BS-7 & $61.42(51.58)$ & $\mathrm{H}$ \\
\hline 8 & BS-8 & $31.08(33.87)$ & M \\
\hline 9 & BS-9 & $61.00(51.00)$ & $\mathrm{H}$ \\
\hline 10 & BS-10 & $18.72(25.63)$ & $\mathrm{L}$ \\
\hline 11 & BS-11 & $17.97(25.07)$ & $\mathrm{L}$ \\
\hline 12 & BS-12 & $14.23(22.15)$ & $\mathrm{L}$ \\
\hline 13 & BS-13 & $35.34(36.46)$ & M \\
\hline 14 & BS-14 & $32.53(34.76)$ & M \\
\hline 15 & BS-15 & $18.83(25.78)$ & $\mathrm{L}$ \\
\hline 16 & BS-16 & $63.42(52.77)$ & $\mathrm{H}$ \\
\hline 17 & BS-17 & $14.05(22.01)$ & $\mathrm{L}$ \\
\hline 18 & BS-18 & $31.08(33.87)$ & M \\
\hline 19 & BS-19 & $61.20(51.20)$ & $\mathrm{H}$ \\
\hline 20 & BS-20 & $14.60(22.45)$ & $\mathrm{L}$ \\
\hline 21 & BS-21 & $12.73(20.88)$ & $\mathrm{L}$ \\
\hline 22 & BS-22 & $53.70(47.11)$ & $\mathrm{H}$ \\
\hline 23 & BS-23 & $26.21(30.79)$ & M \\
\hline 24 & BS-24 & $22.84(28.54)$ & M \\
\hline 25 & BS-25 & $18.87(25.74)$ & $\mathrm{L}$ \\
\hline 26 & BS-26 & $24.84(32.54)$ & M \\
\hline 27 & BS-27 & $56.48(48.70)$ & $\mathrm{H}$ \\
\hline 28 & BS-28 & $35.34(36.46)$ & M \\
\hline 29 & BS-29 & $32.08(34.87)$ & M \\
\hline 30 & BS-30 & $57.40(49.24)$ & $\mathrm{H}$ \\
\hline 32 & Check & $56.00(48.00)$ & $\mathrm{H}$ \\
\hline \multirow[t]{3}{*}{32} & Control & $00.00(0.00)$ & $\mathrm{L}$ \\
\hline & S.Em \pm & 0.32 & \\
\hline & C.D at $1 \%$ & 0.91 & \\
\hline
\end{tabular}

$>40 \%=\operatorname{High}(\mathrm{H})=11 ; 20-40 \%=$ Moderate $(\mathrm{M}=11$

$<20 \%=$ Low $(\mathrm{L})=10$; *Figures in the parentheses are arc sine values 
In conclusion, $B$. subtilis exhibited sufficient antibiosis capability due to its good inhibitory performance against $C$. capsici. B. subtilis strains with good antimicrobial properties have been used as an alternative to chemical pesticides in disease management strategy and should be further studied under field condition and possibly scaled-up for the control of numerous phytopathogenic fungi causing diseases and great yield losses.

\section{References}

Aliye, A. N., Fininsa, B. C. and Hiskias, Y., 2008, Evaluation of rhizosphere bacterial antagonists for their potential to bioprotect potato (Solanum tuberosum) against bacterial wilt (Ralstonia solanacearum) Biol. Cont., 47: 282-288.

Anand, M., Naik, M. K., Ramegowda, G. and Devika Rani, G. S., 2010, Biocontrol and plant growth promotion activity of indigenous isolates of Pseudomonas fluorescens. J. Mycopathol. Res., 48(1): 45-50.

Ashwini, N. and Srividya, S., 2012, Study of mycolytic enzymes of Bacillus spp. against

Colletotrichum gloeosporioides causing anthracnose in Chilli. Acta Biologica Indica, 1(1):81-89.

Dinesh Singh, Yadav, D. K., Shweta, S. and Upadhyay, B. K., 2012, Utilization of plant growth promoting Bacillus subtilis isolates for the management of bacterial wilt incidence in tomato caused by Ralstonia solanacearum race 1 biovar 3. Indian Phytopath., 65(1): 18-24.

Gerhardson, B., 2002, Biological substitutes for pesticides: Trends in Biotechnology, 20: 338-343.

Glick, B. R., 1995, The enhancement of plant growth promotion by free-living bacteria. Can. J. Microbiol., 41: 9-17.
Haggag, W. M. and Timmusk, S., 2008, Colonization of peanut roots by biofilm-forming Paenibacillus polymyxa initiates biocontrol against crown rot disease. J. Applied Microbiol. 104: 961-969.

Ji, X., Yingping, L., Zheng, I. G. and Zhimei, M., 2008, Biological control against bacterial wilt and colonization of mulberry by an endophytic Bacillus subtilis strain. FEMS. Microbiol. Ecol., 65: 565-573.

Korsten, L. and De Jager, E. S., 1995, Mode of action of Bacillus subtilis for control of avocado post-harvest pathogens. South African Avocado Growers' Association Yearbook 18:124-130.

Lemessa, F. and Zeller, W., 2007, Screening rhizobacteria for biological control of Ralstonia solanacearum in Ethiopia. Biological Control, 42:336-344.

Loeffler, W., Kratzer, W., Kremer, S., Kugler, M., Petersen, F., Jung, G., Rapp, C. and Tschen, J. S. M., 1990, Gegen pilze wirksame antibiotika der Bacillus subtilis - Gruppe. Forum Mikrobiol., 3: 156 -163.

Mathiyazhagan, S., 2003, Studies on the soil borne diseases of Phyllanthus amarus (Scham and Thom) and their management. M. Sc. (Agri.) Thesis, Tamil Nadu Agric. Unvi., Coimbatore (India).

Montealegre, J. R., Reyes, R., Pérez, L. M., Herrera, R., Silva, P., and Besoain, X., 2003, Selection of bio antagonistic bacteria to be used in biological control of Rhizoctonia solani in tomato. Electronic J. Biotechnol., 6:34.

Nakano, M. and Hulett, M., 1997, Adaptation of Bacillus subtilis to oxygen limitation. Microbiol., 157( 1): 1-7.

Pankaj Kumar, Dubey, R. C. and Maheshwari, D. K., 2012, Bacillus 
strains isolated from rhizosphere showed plant growth promoting and antagonistic activity against phytopathogens. Asian J. Boil. Life sci., 2(2): 56- 67.

Piggot, P. and Hilbert, D. (2004). Sporulation of Bacillus subtilis. Current Opinion in Microbiol., 7( 6):579-586.

Ramyabharathi, S. A. and Raguchander, T., 2013, Induction of defence enzymes and proteins in tomato plants by Bacillus subtilis EPCO16 against Fusarium oxysporum $f$. sp. lycopersici. Madra. Agric. J., 100(2): 126-130.

Schippers, B., 1992, Prospects for management of natural suppressiveness to control soilborne pathogens. In: biological control of plant diseases, progress and challenges for the future. Life Sciences. Tjamos, E. C., Papavizas, G. C. and Cook, R. J. (eds.). Plenum Press, New York, USA. 230: 21-34.

Sumana, K. and Devaki, N. S., 2013, In vitro evaluation of some bioagents against tobacco wilt. J. Biopest., 5(1): 18-22.

Timmusk, S., Grantcharova, N. and Wagner, E. G. H., 2005, Paenibacillus polymyxa invades plant roots and forms biofilms. Appl. Environ. Microbiol., 11: 7292-7300.

Vincent, J. M., 1927, Distortion of fungal hyphae in presence of certain inhibitors. Nature, 159: 850.

Wafula, E. N., Johnson, K., Daniel, K., Anne, M. and Romano, M., 2014, Isolation and characterization of Bacillus species from soil in Ngere tea catchment area of Murang'a county, Kenya. Int. J. Life Sci. Res., 2(3): 2735 .

\section{How to cite this article:}

Rajkumar, K., M.K. Naik, Y.S. Amaresh and Chennappa, G. 2018. Bioefficacy of Bacillus subtilis against Major Pathogen of Chilli Colletotrichum capsici Causing Fruit Rot of Chilli. Int.J.Curr.Microbiol.App.Sci. 7(07): 2681-2686. doi: https://doi.org/10.20546/ijcmas.2018.707.314 